\title{
ESTABLISHMENT OF THE FUNGAL ENTOMOPATHOGEN Beauveria bassiana AS AN ENDOPHYTE IN COCOA PODS (Theobroma cacao L.)
}

\section{ESTABLECIMIENTO DEL HONGO ENTOMOPATÓGENO Beauveria bassiana COMO ENDÓFITO EN FRUTOS DE CACAO (Theobroma cacao L.)}

Francisco J. Posada', Fabio C. Chaves², Thomas J. Gianfagna ${ }^{3}$, Monica Pava-Ripoll4, Prakash Hebbar ${ }^{5}$

${ }^{1}$ I.A. Ph.D. Programa de Ingeniería Agronómica. Universidad de Ciencias Aplicadas y Ambientales U.D.C.A, Calle 222 No. 54-37, Bogotá, D.C., Colombia. fjavierposada@hotmail.com (corresponding author); ${ }^{2}$ Ph.D. Department of Plant Biology and Plant Pathology, Rutgers, The State University of New Jersey, 59 Dudley road, New Brunswick, NJ 08901 USA. ${ }^{3}$ Biologist, Ph.D. Department of Plant Biology and Plant Pathology, Rutgers, The State University of New Jersey, 59 Dudley Road, New Brunswick, NJ 08901 USA. ${ }^{4}$ Bacteriologist, Ph.D. Department of Entomology, University of Maryland, College Park, MD 20742, USA. ${ }^{5}$ Microbiologist, Ph.D. US Department of Agriculture-APHIS-PPQ, Emergency \& Domestic Programs, 4700 River Road \# 5C-0340. Riverdale, Maryland, USA, 20737.

Rev. U.D.C.A Act. \& Div. Cient. 13 (2): 71-78, 2010

\section{ABSTRACT}

The entomopathogenic fungus Beauveria bassiana was re-isolated from surface sterilized pieces of the cocoa pod outer section and peduncle, two and three months after flowers of greenhouse cocoa plants were hand-pollinated and sprayed with a $1 \times 10^{7} \mathrm{~mL}^{-1}$ suspension of $B$. bassiana conidia. The colonization frequency of $B$. bassiana on cocoa pods was $0.8 \%$ and $1.3 \%$ two and three months post-spraying of conidial suspension, respectively. These results indicate that this entomopathogenic fungus can be established as an endophyte on cocoa pods if flowers are sprayed. Other naturally occurring endophytic fungi such as Acremonium spp., Aspergillus spp., Cladosporium spp. and Penicillium spp. as well as seven morphospecies of bacteria were also isolated from cocoa pods. These findings suggest that cocoa pods are conducive for endophytic fungal growth of both naturally occurring and inoculated $B$. bassiana, and could possibly lead to an innovative methodology to manage insect pests in biocontrol programs.

Key words: Ascomycota, hypocreales, biological control, endophytes, entomopathogens, Theobroma cacao.

\section{RESUMEN}

El hongo entomopatógeno Beauveria bassiana fue re-aislado de superficies desinfectadas de fragmentos de la parte externa y del pedúnculo del fruto de cacao luego de dos y tres meses de que las flores de plantas criadas en invernadero fueran polinizadas manualmente y asperjadas con una suspensión de $1 \times 10^{7} \mathrm{~mL}^{-1}$ esporas de $B$. bassiana. La frecuencia de colonización de $B$. bassiana en el fruto de cacao fue de $0,8 \%$ y $1,3 \%$ luego de dos y tres meses de la aspersión de las esporas, respectivamente. Estos resultados indican que este hongo entomopatógeno puede ser establecido como hongo endófito de frutos de cacao luego de la aspersión de las flores de caco con esporas del hongo. Durante el estudio, también se aislaron otros hongos endófitos del fruto de cacao como Acremonium spp., Aspergillus spp., Cladosporium spp. y Penicillium spp, y siete morfoespecies de bacterias, demostrando su presencia natural como endófitos de esta planta. Estos resultados sugieren que los frutos de cacao contribuyen al crecimiento tanto de hongos endófitos naturales como del hongo $B$. bassiana inoculado, y esto podría conllevar al establecimiento de una metodología novedosa para el manejo de insectos perforadores de frutos de cacao en programas de control biológico de insectos plaga.

Palabras clave: Ascomycota, hypocreales, control biológico, endófitos, entomopatógenos, Theobroma cacao. 


\section{INTRODUCTION}

Fungal endophytes live naturally in plants without causing any apparent infection (Maheshwari, 2006). A vast number of naturally occurring fungal endophytes have been identified and these include several entomopathogenic fungi such as Beauveria bassiana (Balsamo) Vuillemin (Ascomycota: Hypocreales) (Vega et al. 2008). This fungus has also been artificially established as an endophyte to control insect pests on different plant species such as banana (Musa sp.) (Akello et al. 2009), maize (Zea mays) (Wagner $\&$ Lewis, 2000; Cherry et al. 2004), date palm (Phoenix dactylifera) (Gómez-Vidal et al. 2006), opium poppy (Papaver somniferum Vault) (QuesadaMoraga et al. 2006), coffee (Coffea arabica L.) (Posada et al. 2007; Posada \& Vega 2006) and cocoa (Theobroma cacao L.) (Posada E Vega, 2005).

Artificial inoculations of plants with conidial suspension of $B$. bassiana have been applied using several methods such as, seed soaking, soil drenching, leaf spraying, stem injection, and ridicule inoculation (Posada \& Vega, 2005; 2006; Posada et al. 2007). However, the establishment of this fungus on other plant parts, such as flowers or fruits, has not been fully explored. Spraying flowers with a conidial suspension of $B$. bassiana may provide protection against economically important insect pests that feed upon fruits and pods. Yet, to use this methodology, it is important to consider that in most plants, the numbers of flowers usually exceeds the numbers of mature fruits since both internal and external factors induce the abortion of flowers and immature fruits (Stephenson, 1981).

The flowers also attract beneficial insects that have been used to inoculate fungal conidias of biological insecticides. For instance, insect pollinators such as bees and bumblebees have vectored conidia of fungal agents such as Trichoderma harzianum Rifai and Gliocladium roseum Bainier (= Clonostachys rosea (Link: Fries) Schroers, Samuels, Seifert and Gams) to control Botrytis cinerea on strawberries (Peng et al. 1992; Yu \& Sutton, 1997; Kovach et al. 2000; Shafir et al. 2006). Similarly, the dissemination of entomopathogenic fungi by insects has been studied in many agricultural ecosystems (Vega et al. 2007) and bees have also been used to disseminate Metarhizium anisopliae (Metchnikoff) Sorokin on oilseed rape flowers to reduce populations of the pollen beetle, Meligethes aeneus Fabricius (Butt et al. 1998). However, none of these insectmediated dissemination studies focused on the establishment of $B$. bassiana as a plant endophyte.

The establishment of $B$. bassiana as an endophyte in cocoa plants may be used to control insect pests that attack cocoa pods through the world, including the cocoa bug, Monalonium spp. (Hemiptera: Miridae) in America (Montealegre E Rodríguez, 1989) and the cocoa pod borer, Conopomorpha cramerella
Snellen (Lepidoptera: Gracillariidae) in Southeast Asia (Flood et al. 2004). Monalonium spp sucks the cocoa fruits and $C$. cramerella borers the pods, both causing significant economic losses. C. cramerella adults lay their eggs on the cocoa pod and larvae enter the pod, feeding on the seed endosperm. The larvae eventually exit the pod and pupate in the leaf litter, with subsequent adult emergence. Larval feeding causes petrifaction and clumping of cocoa beans and premature pod ripening. Several reports indicate that both insect pests are susceptible to $B$. bassiana (Lim et al. 1988; Montealegre \& Rodríguez, 1989; Wiryadiputra, 2001).

The objective of this experiment was to explore the flower inoculation methodology to establish $B$. bassiana as an endophyte in cocoa pods. After conidial inoculation on flowers, several pods were sampled monthly for a period of five months to evaluate the establishment of this fungus as an endophyte on cocoa pods. This study also reports the naturally occurring fungal and bacterial endophytes present on different parts of the cocoa pod over a period of time. This would be the first attempt to determine whether the flower inoculation methodology can be used to establish the entomopathogenic fungus $B$. bassiana as an endophyte of cocoa pods.

\section{MATERIAL AND METHODS}

The isolate of $B$. bassiana used to spray the cocoa flowers was Bb04005 and was obtained from Sustainable Perennial Crops Laboratory, US Department of Agriculture in Beltsville, MD. This isolate was originally isolated from a yellow jacket wasp (Vespula sp.; Hymenoptera: Vespidae), thus ensuring its entomopathogenicity. Before running the experiment, we determined the percentage of germination of this $B$. bassiana strain. For this, $15 \mu \mathrm{L}$ of the conidial suspension were plated per triplicate, on 2.5\% Noble agar (Becton Dickinson, Sparks, MD) and incubated at $25 \pm 2^{\circ} \mathrm{C}$ for 24 hours. After the incubation time, three subsets of agar pieces $\left(1 \mathrm{~cm}^{2}\right)$ were sampled per plate, slide mounted and observed under the microscope. One hundred conidia were observed per subsample and assessed for the presence of the germ tube.

The experiment used eight 15-year old "Amelonado" cocoa trees growing in greenhouses at Rutgers University (New Brunswick, NJ). The flowers of four trees (60 flowers per tree) were sprayed with $1 \times 10^{7} B$. bassiana conidia suspended in $0.1 \%$ Triton X-100 (Sigma-Aldrich Co., St. Louis, MO) (+Bb). The flowers of the remaining trees ( 60 flowers per tree) were sprayed with autoclaved $0.1 \%$ Triton X-100 (control) (-Bb). The treatments were applied after the cocoa flowers were hand-pollinated. Spray applications were performed using a hand-held Jet-Pak spray system (Sprayon Products, Inc., Cleveland, $\mathrm{OH}$ ). After spraying, flowers were individually covered with plastic bags to increase humidity content and promote germination of fungal conidia. 
Flowers set fruits and cocoa pods were collected each month after spraying for a period of five months. Pods were evaluated for the presence of fungal and bacterial endophytes and for the colonization frequency of $B$. bassiana within the pod. Each month, two to five pods from each treatment were harvested. Individual pods were cut open into four transversal sections plus the peduncle (Figure 1). The husk of each transversal section was divided in two parts: outer and inner parts (Figure 1 \#1-4 and \#5-8, respectively), and the peduncle was divided into two parts: one attached to the pod and the other attached to the tree (Figure $1 \# 9$ and \#10, respectively). The pieces were surface sterilized by submerging them in $0.5 \%$ sodium hypochlorite for two minutes, $70 \%$ ethanol for two minutes, and then rinsed in sterile water (Arnold et al. 2001). They were subsequently dried with sterile tissue paper and the brownish edges were removed using a sterile scalpel. Each piece was subsequently cut in fragments of ca. $3 \times 4 \mathrm{~mm}$ and six fragments were placed on Petri dishes containing yeast malt agar (YMA; Sigma-Aldrich Co., St Louis, MO) plus antibiotics as described previously by Posada $\mathcal{E}$ Vega (2005). Thus a total of 60 pieces were evaluated per pod: 24 from the outer part of the pod, 24 from the inner part, and 12 from the peduncle (Figure 1). Plates were incubated at $25 \pm 2^{\circ} \mathrm{C}$ in a $12: 12$ photoperiod and observed for fungal development for two months. Fungal colonies that were developing from cocoa pieces were counted and then individually isolated on fresh YMA plates, incubated as described before and identified using various taxonomic keys (St. Germain \& Summerbell, 1996; Barnett \& Hunter, 1998; Watanabe, 2002). Bacterial colonies growing on YMA plates were counted and grouped as morphospecies according to colony characteristics: morphology, color and shape.

The number of colonies of endophytic bacteria and fungi present on pod pieces over time were recorded. The colonization frequency of $B$. bassiana was expressed using the formula of Fisher and Petrini (1987) [colonization frequency= $100 \mathrm{x}$ (pieces colonized by a single endophyte / total number of pieces evaluated)].

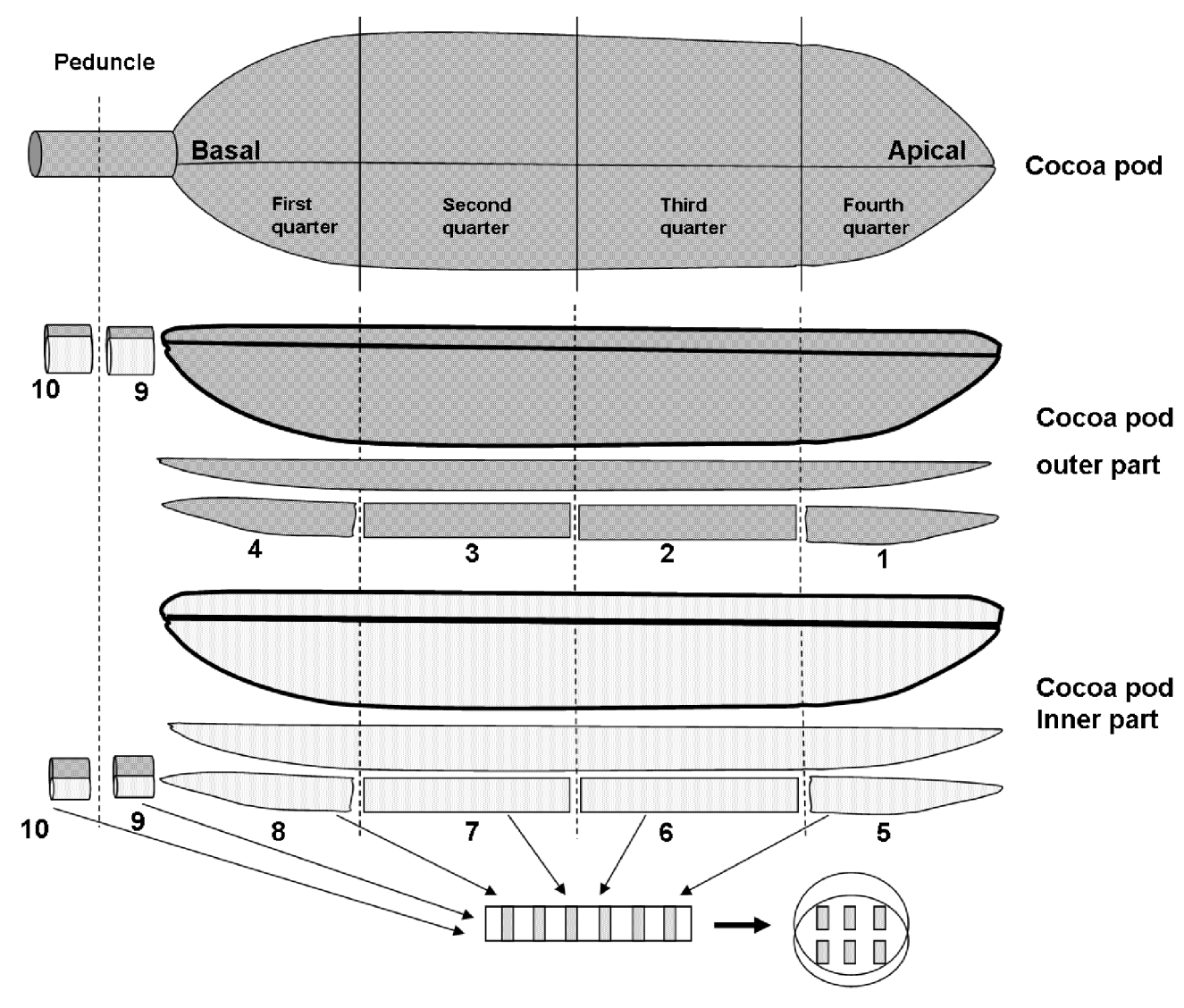

Figure 1. Cocoa pod sections sampled for presence of naturally occurring endophytic fungi and bacteria and for Beauveria bassiana after flowers were sprayed with a conidial suspension (+Bb) or with sterile water plus $0.1 \%$ Triton X-100 (control) (-Bb). For each section (labeled 1 to 10 in the figure), six pod pieces were plated on yeast malt agar (YMA). 
To assess the quality of the surface sterilization method, $15 \mu \mathrm{L}$ of the water used to rinse the pieces after they were surface sterilized were plated on YMA plus antibiotics (Posada \& Vega, 2005). Plates were evaluated for the presence of endophytic microorganisms four days after inoculation

\section{RESULTS AND DISCUSSION}

This is the first report of the establishment of the entomopathogen fungus $B$. bassiana as an endophyte in fruits (cocoa pods) after the flowers were sprayed with a conidial suspension. The germination of $B$. bassiana Bb04005 conidia was $>90 \%$. The evaluation of surface sterilized water did not yield any microorganisms, thus assuring that the external surface of the pods and peduncles were properly surface sterilized.

The cacao plant produced a high number of flowers, however the abortion rate of flowers and immature fruits is very high, and generally no more than $5 \%$ of the flowers develop into mature fruits (Bos et al. 2007). Hence, it is not surprising that from 480 flowers that were hand pollinated and sprayed, only 40 set fruits (8.3\%) and 30 developed to maturity (6.3\%): 16 of them were sprayed with $B$. bassiana $(+\mathrm{Bb})$ and 14 were controls $(-\mathrm{Bb})$. Two and four pods were sample per treatment in the first and second month post-spraying, respectively. Five pods were sampled from $(+\mathrm{Bb})$ treatments whereas three pods were sampled from $(-\mathrm{Bb})$ plants in the third month. In the fourth and fifth month, three and two pods were sampled from $(+\mathrm{Bb})$ treatments, respectively, whereas two and three pods were sampled from (-Bb) treatments, respectively. The total number of pod pieces evaluated were 960 in the $(+\mathrm{Bb})$ treatment and 840 in the (-Bb) treatment.

Because the symbiotic or antagonistic effects of the ecological associations of endophytic microorganism are not clear in most of the host plants, it is important to have as much knowledge as possible of the endophytic microbial community present in a particular plant. This will help to establish possible ecological associations among them and ensure the successful establishment of fungal entomopathogens. Results from this study show that several fungal and bacterial endophytes were recovered from different parts of cocoa pods and peduncle in both $(+\mathrm{Bb})$ and $(-\mathrm{Bb})$ sprayed flowers, at each month of evaluation. The total number of colonies of endophytic fungi found one, two, three, four and five months post-spraying were $51,92,67,62$ and 27, respectively, on (+Bb) treatments and 133, 103, 28, 57 and 34, respectively, on (-Bb) treatments. Fungal colonies recovered from cocoa pod pieces belong to nine endophytic fungi that were identified using morphological traits. One fungus was identified to species level: $B$. bassiana; four fungi were identified to genus level: Acremonium sp., Aspergillus sp., Cladosporium sp. and Penicillium sp.; and four fungi were identified to morphospecies. Aspergillus sp., Cladosporium sp. and Penicillium sp. were recovered as endophytes at each evaluation time (Table 1). The number of colonies of Penicillium sp. was predominant in both pod and peduncle pieces and was followed by Aspergillus sp. Rubini et al. (2005) reported the diversity of endophytic fungi on branches of cocoa trees in Brazil; Acremonium sp. and Cladosporium sp. were recovered among those ones, but Penicillium sp. and Aspergillus sp. were not, thus indicating that the presence of these last two fungi is probably limited to the cocoa pods.

Lower numbers of endophytic bacteria colonies were found on cocoa pod pieces over time. The total number of colonies of endophytic bacteria found one, two, three, four and five months post-spraying were $0,27,10,0$ and 1 , respectively, on $(+\mathrm{Bb})$ treatments and $1,7,5,7$ and 0 , respectively, on (-Bb) treatments. Bacterial colonies recovered from cocoa pod pieces belong to seven different bacteria that were identified as morphospecies. Posada $E$ Vega (2005) also reported five morphospecies of bacteria from different parts of cocoa seedlings inoculated with $B$. bassiana (seedling inoculation method) and also from the control treatments. However, their associations with fungal endophytes are yet to be determined.

$B$. bassiana is reported as a natural endophyte in C. arabica (Vega et al. 2010) and Theobroma gileri (Evans et al. 2003). However, $B$. bassiana was never recovered from the control pods (-Bb) in our study. This fungus was neither found as an endophyte on branches from cocoa trees (Rubini et al. 2005) or cocoa seedlings (Posada $E$ Vega, 2005), thus indicating that $B$. bassiana may not be naturally present as an endophyte on $T$. cacao. However, B. bassiana was recovered from outer section of $(+\mathrm{Bb})$ pods, two and three months post-spraying (Table 1). At two months post-spraying, 240 cocoa pod pieces, belonging to four pods, were evaluated and 92 fungal colonies were recovered from those pieces (Table 1). Two of those fungal colonies (2.2\%) were positively identified as $B$. bassiana (one from the third quarter of the pod and another from the peduncle of the same pod) (Table 1). Thus, at two months post-spraying, one out of four pods evaluated $(25 \%)$ was positive for $B$. bassiana and the colonization frequency was $0.8 \%(2 / 240 * 100)$. At three months post-spraying with $B$. bassiana, 300 cocoa pod pieces, belonging to five pods, were evaluated and 67 fungal colonies were recovered from those pieces. Four of those fungal colonies $(5.9 \%)$ were identified as $B$. bassiana (all from the fourth quarter of the same pod) (Table 1). Thus, at three months post-spraying, one out of five pods evaluated (20\%) was positive for $B$. bassiana and the colonization frequency was $1.3 \%(4 / 300 * 100)$.

Although the colonization frequency of $B$. bassiana in cocoa pods was at low levels $(0.8 \%$ and $1.3 \%$ two and three months 


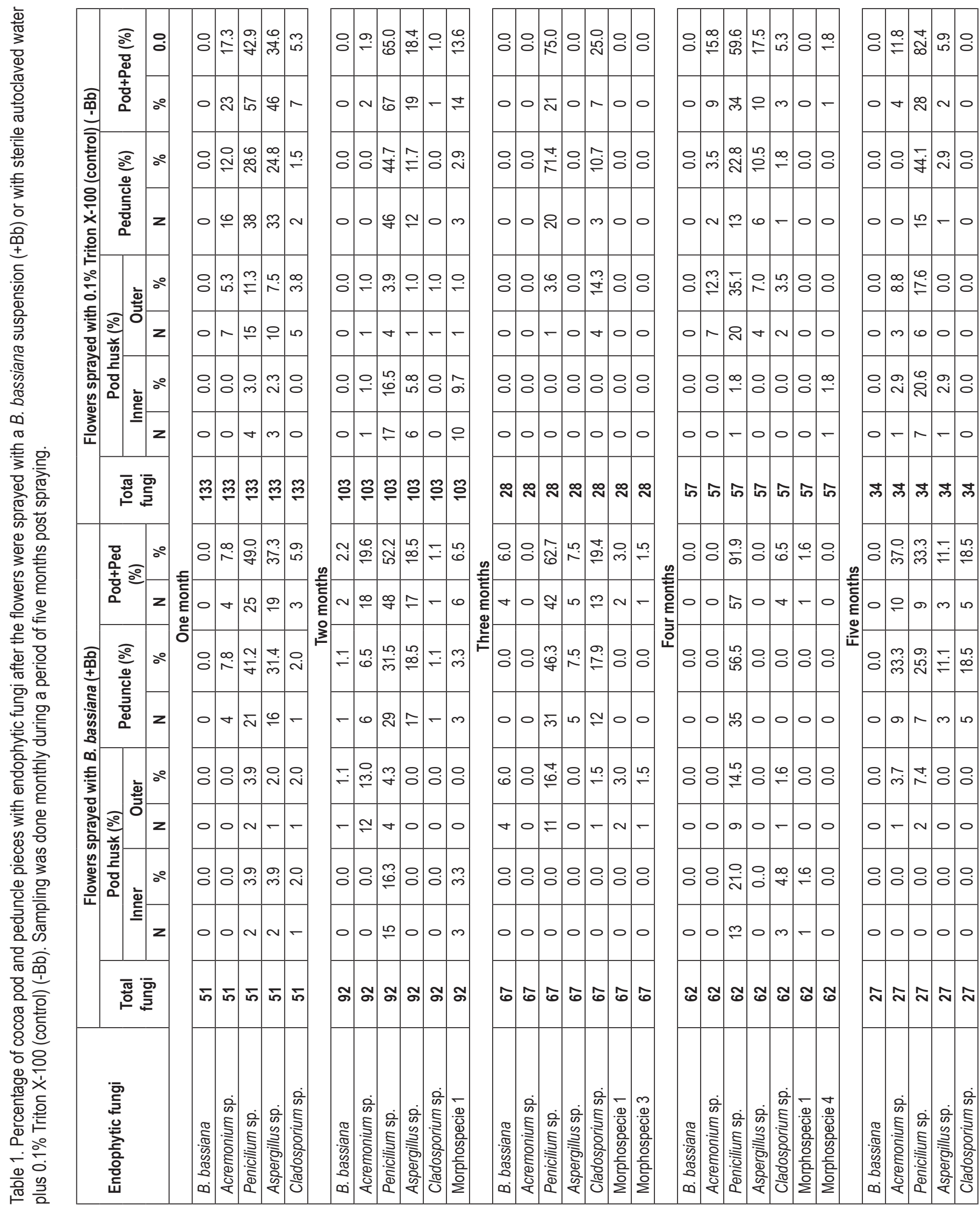


post-spraying, respectively), Suryanarayanan $\mathcal{E}$ Thennarasa (2004) reported that in Plumeria rubra, a tropical ornamental tree, colonization frequencies of a particular naturally occurring endophytic fungus (i.e. Cladosporium sp. 1) can be as low as $0.5 \%$ at a particular time point. The colonization frequency of naturally occurring endophytes increases as the plant ages because they seem to accumulate from the environment over time (Suryanarayanan E Thennarasan, 2004; Guo et al. 2008). Therefore, the establishment of $B$. bassiana on cocoa pods of younger cocoa trees should be evaluated to avoid possible antagonistic interactions with already established endophytic microorganisms.

Plants produce chemical compounds for protecting the flowers against infections caused by pests and diseases and also for regulating pollen compatibility (Ngugi \& Scherm, 2006). B. bassiana isolate Bb04005 was able to overcome this adverse environment indicating that the flower inoculation method could potentially be used to establish entomopathogenic biocontrol agents as endophytes in pods or fruits, sites that need constant protection against economically important insect pests. However, because the natural high abortion rate of flowers in cocoa trees can be up to 95\% (Young, 1994; Ramos et al. 2005), further experiments with higher number of sprayed flowers will be required to evaluate the colonization frequency of $B$. bassiana on a greater number of cocoa pods.

The diversity of fungi and bacteria found naturally as endophytes in cocoa pods and peduncles and the interactions among them and with $B$. bassiana is an additional component that needs to be studied in more detail. The presence of $B$. bassiana on cocoa pods did not induce noticeable disease symptoms, therefore the fungus is apparently innocuous to the plant. Its capability to be established on the peduncle and move further into the pod as it grows, demonstrated that it could spread systematically on the pod. Further experiments are planned to select $B$. bassiana isolates with better endophytic capability and to improve formulations for the delivery of this entomopathogenic fungus.

Using the flower inoculation method to establish $B$. bassiana as an endophyte in cocoa pods brings several questions to the forefront: (1) Which mechanisms are used by $B$. bassiana to colonize the flower? (2) Are some $B$. bassiana isolates better suited than others to grow endophytically in cocoa pods? (3) Will $B$. bassiana also become established on the cocoa seeds? (4) Can B. bassiana move from the pod to other parts of the plant? Answers to these questions, along with improvements in the successful establishment of $B$. bassiana in the cocoa pods might result in a novel biocontrol method against $C$. cramerella in Southeast Asia and Monalonium spp. in America.

Acknowledgments. We thank Ann Simpkins from the US Department of Agriculture, Agriculture Research Service, in
Beltsville, MD for outstanding laboratory assistance and MARS and USDA-CRADA for financial support.

\section{REFERENCES}

1. AKELLO, J.; DUBOIS, T.; COYNE, D.; KYAMANYWA, S. 2009. The effects of Beauveria bassiana dose and exposure duration on colonization and growth of tissue cultured banana (Musa sp.) plants. Biol. Control. 49:6-10.

2. ARNOLD, A.E.; MAYNARD, Z.; GILBERT, G.S. 2001. Fungal endophytes in dicotyledonous neotropical trees: patterns of abundance and diversity. Mycol. Res. 105:1502-1507.

3. BARNETT, H.L.; HUNTER, B.B. 1998. Illustrated Genera of Imperfect Fungi APS Press: Saint Paul. 218p.

4. BOS, M.M.; STEFFAN-DEWENTER, I.; TSCHARNTKE, T. 2007. Shade tree management affects fruit abortion, insect pests and pathogens of cacao. Agriculture Ecosystems \& Environment. 120:201-205.

5. BUTT, T.M.; CARRECK, N.L.; IBRAHIM, L.; WILLIAMS, I.H. 1998. Honey-bee-mediated infection of pollen beetle (Meligethes aeneus Fab.) by the insect-pathogenic fungus, Metarhizium anisopliae. Biocontrol Science and Technology. 8:533-538.

6. CHERRY, A.; BANITO, A.; DJEGUI, D.; LOMER, C. 2004. Suppression of the stem-borer Sesamia calamistis (Lepidoptera; Noctuidae) in maize following seed dressing, topical application and stem injection with African isolates of Beauveria bassiana. Internal J. Pest Management. 50:67-73.

7. EVANS, H.C.; HOLMES, K.A.; THOMAS, S.E. 2003. Endophytes and mycoparasites associated with an indigenous forest tree, Theobroma gileri, in Ecuador and a preliminary assessment of their potential as biocontrol agents of cocoa diseases. Mycol. Progress. 2:149-160.

8. FISHER, P.J.; PETRINI, O. 1987. Location of fungal endophytes in tissues of Suaeda fruticosa - a preliminary study. Transactions of the British Mycological Soc. 89:246-249.

9. FLOOD, J.; GUEST, D.; HOLMES, K.A.; KEANE, P.; PADI, B.; SULISTYOWATI, E. 2004. Cocoa under attack. In: Flood, J.; Murphy R. eds. Cocoa Futures: A Source Book of Some Important Issues Confronting the Cocoa 
Industry. Chinchiná, Colombia. CABI-FEDERACAFÉUSDA, p.33-53.

10. GÓMEZ-VIDAL, S.; LOPEZ-LLORCA, L.V.; JANSSON, H.B.; SALINAS, J. 2006. Endophytic colonization of date palm (Phoenix dactylifera L.) leaves by entomopathogenic fungi. Micron. 37:624-632.

11. GUO, L.D.; HUANG, G.R.; WANG, Y. 2008. Seasonal and tissue age influences on endophytic fungi of Pinus tabulaeformis (Pinaceae) in the Dongling Mountains, Beijing. J. Integrative Plant Biol. 50:997-1003.

12. KOVACH, J.; PETZOLDT, R.; HARMAN, G.E. 2000. Use of honey bees and bumble bees to disseminate Trichoderma harzianum 1295-22 to strawberries for Botrytis control. Biol. Control. 18:235-242.

13. LIM, T.K.; RITA, M.; OOI, P.A.C.; CHIN, C.L. 1988. Some entomopathogenic fungi isolated from Conopomorpha cramerella. Planter 64:548-554.

14. MAHESHWARI, R. 2006. What is an endophytic fungus? Current Science 90:1309.

15. MONTEALEGRE, R.J.; RODRÍGUEZ, D.A. 1989. Patogenicidad del hongo Beauveria bassiana (Bals.) Vuill. sobre la chinche Monalion dissimulatum Distant plaga del cacaotero Theobroma cacao L. Acta Agronomica. 39:88-96.

16. NGUGI, H.K.; SCHERM, H. 2006. Biology of flowerinfecting fungi. Ann. Rev. Phytopathology. 44:261-282.

17. PENG, G.; SUTTON, J.C.; KEVAN, P.G. 1992. Effectiveness of honey-bees for applying the biocontrol agent Gliocladium roseum to strawberry flowers to suppress Botrytis cinerea. Can. J. Plant Pathology-Revue Canadienne de Phytopathologie. 14:117-129.

18. POSADA, F.; AIME, M.C.; PETERSON, S.W.; REHNER, S.A.; VEGA, F.E. 2007. Inoculation of coffee plants with the fungal entomopathogen Beauveria bassiana (Ascomycota : Hypocreales). Mycol. Res. 111:748-757.

19. POSADA, F.; VEGA, F.E. 2005. Establishment of the fungal entomopathogen Beauveria bassiana (Ascomycota : Hypocreales) as an endophyte in cocoa seedlings (Theobroma cacao). Mycologia 97:1195-1200.

20. POSADA, F.; VEGA, F.E. 2006. Inoculation and colonization of coffee seedlings (Coffea arabica L.) with the fungal entomopathogen Beauveria bassiana (Ascomycota: Hypocreales). Mycoscience. 47:284-289.
21. QUESADA-MORAGA, E.; LANDA, B.B.; MUNOZ-LEDESMA, J.; JIMENEZ-DIAZ, R.M.; SANTIAGO-ALVAREZ, C. 2006. Endophytic colonisation of opium poppy, Papaver somniferum, by an entomopathogenic Beauveria bassiana strain. Mycopathologia 161:323-329.

22. RAMOS, A.R.; VENTURIERI, G.; CUCO, S.M.; CASTRO, N.M. 2005. The site of self-incompatibility action in cupuassu (Theobroma grandiflorum). Rev. Brasil. Bot. 28:69-578.

23. RUBINI, M.R.; SILVA-RIBEIRO, R.T.; POMELLA, A.W.V.; MAKI, C.S.; ARAÚJO, W.L.; DOS SANTOS, D.R.; AZEVEDO, J.L. 2005. Diversity of endophytic fungal community of cacao (Theobroma cacao L.) and biological control of Crinipellis perniciosa, causal agent of Witches' Broom Disease. Internal J. Biological Sciences. 1:24-33.

24. SHAFIR, S.; DAG, A.; BILU, A.; ABU-TOAMY, M.; ELAD, Y. 2006. Honey bee dispersal of the biocontrol agent Trichoderma harzianum T39: effectiveness in suppressing Botrytis cinerea on strawberry under field conditions. European J. Plant Pathology. 116:119-128.

25. ST. GERMAIN, G.; SUMMERBELL, R. 1996. Identifying filamentous fungi: A clinical laboratory handbook Star Publishing Company: Belmont, CA. 314p.

26. STEPHENSON, A.G. 1981. Flower and Fruit Abortion Proximate Causes and Ultimate Functions. Ann. Rev. Ecology and Systematics. 12:253-279.

27. SURYANARAYANAN, T.S.; THENNARASAN, S. 2004. Temporal variation in endophyte assemblages of Plumeria rubra leaves. Fungal Diversity. 15:197-204.

28. VEGA, F.E.; DOWD, P.F.; LACEY, L.A.; KLEIN, M.G. 2007. Dissemination of beneficial microbial agents by insects. . En: Lacey, L.A.; Kaya, H., eds. Field Manual of Techniques in Invertebrate Pathology. Springer, The Netherlands. p.18.

29. VEGA, F.E.; POSADA, F.; AIME, M.C.; PAVA-RIPOLL, M.; INFANTE, F.; REHNER, S.A. 2008. Entomopathogenic fungal endophytes. Biol. Control. 46:72-82.

30. VEGA, F.E.; SIMPKINS, A.; AIME, M.C.; POSADA, F.; PETERSON, S.W.; REHNER, S.A.; INFANTE, F.; CASTILLO, A.; ARNOLD, A.E. 2010. Fungal endophyte diversity in coffee plants from Colombia, Hawai' i, Mexico and Puerto Rico. Fungal Ecology. 3:122-138. 
31. WAGNER, B.L.; LEWIS, L.C. 2000. Colonization of corn, Zea mays, by the entomopathogenic fungus Beauveria bassiana. Applied and Environmental Microbiology. 66:3468-3473.

32. WATANABE, T. 2002. Pictorial atlas of soil and seed fungi. Morphologies of cultured fungi and key to species CRC Press: Boca Raton, FL. 486p.

33. WIRYADIPUTRA, S. 2001. The use of entomopathogenic fungus (Beauveria bassiana) to control cocoa pod borer (Conopomorpha cramerella) in the field. En: Incoped 3rd International Seminar. Kota Kinabalu Sabah, Malaysia, p.27-32.
34. YOUNG, A.M. 1994. The Chocolate Tree: A Natural History of Cacao Smithsonian Institution Press: Washington, DC. 200p.

35. YU, H.; SUTTON, J.C. 1997. Effectiveness of bumble bees and honeybees for delivering inoculum of Gliocladium roseum to raspberry flowers to control Botrytis cinerea. Biol. Control 10:113-122.

Received: August 25, 2010

Accepted: November 3, 2010 